\title{
PRESERVING ARAB TRADITION The Cultural Expression of Habsyian in East Kalimantan
}

\author{
Akh. Bukhari \\ IAIN Samarinda - Indonesia | bukhariahmad101256@gmail.com
}

\begin{abstract}
The Habsyian tradition is one of well-preserved Arabic traditions in East Kalimantan. The tradition is the recitation of shalawat and historical narratives (maulid) and poems about the Prophet Muhammad in a melody. The rhyme of maulid follows the book of Simt al-Durar written by Yemeni scholar, 'Ali b. Muḥammad b. Husayn al-Ḥabshi (d. 1913). The Habsyian was initially conveyed by some imigrants of Banjar working as traders and missionaries. They share musical instrument like tambourine (rebana) to advance the tradition of people reciting shalawat and story in maulid and it attracts attention. This is how the tradition of Habsyiyan begun and mixed with local tradition. Furthermore, the tradition has functioned as media for social bond that successfully promote unity of varied elements within the society regardless of age differences, social classes, and others. In this case, although the Habsyian tradition was originated from non-local tradition, its movement has played a pivotal role in promoting peace and social harmony life.
\end{abstract}

Keywords: Arab tradition, cultural expression, Habsyian, East Kalimantan.

\section{Introduction}

Discussion on the tradition of Arabic arts influenced in Indonesian heritage should always be correlated to the historical background of the arrival of Arabian traders in Indonesia. The Arab itself has a long historical root. They are originated from Caucasoid race, the submediterranean race whose members largely encompass the areas 
around Mediterranean, Africa, North Armenia, Arab and Iran. ${ }^{1}$ The arrival and spreading of Islam in Indonesia is unique as it has special relation with the existing local cultures. The relation here is the ways in which each has influenced one another. The presence of Islam did not eliminate the existing traditions.

Rather, Islam has spreaded in a harmnious relation with the local culture. Instead of diminishing the local tradition, Islam has actually preserved it's existence with added misture of Islamic values. Due to the adaptive naturecontained in the local culture, Islam in Indonesia has inherited an acculturative tradition that goes from generation to generation. Here, one example of such acculturation is the Habsyi tradition. The Habsyian tradition are held to commemorate some notable events like Muhammad's birthday, the journey of the prophet (isra' mi'rāj), the local tradition of salvation (selamatan), giving name to the newborn child (tasmiyahan). The occasions usually take place in mosques and the houses of the people haing the occaions. It usually begins with poems and prayers upon the prophet Muhammad recited by local scholar.

Historically, the Habsyian has been established by Zaini Ghani, or Ijai, a local scholar who is a direct descendant to the highly-respected figure called as Tuan Guru Shaykh Arsyad Al-Banjari Kalampayan. It is due to his role that Arab tradition steeped in the religious expression of local society in East Kalimantan. ${ }^{2}$ The cultural performance of Habsyian is like a fusion of religious values from Arab assimilating with local culture and belief. The tradition is unique and typical to East Kalimantan as it is not found in other regions. In Sulawesi for instance, the local society performed other cultural expressions called barzanji using another religious book on Muhammad stories.

Habsyian is a cultural arts consisting of the recitation of lyrics and shalawat or prayers upon the Messanger Muhammad PBUH. This is a religious tradition as it is based on the order from Allah stated in verse 56 of Sura Al-Ahzab. Șalawat from Allah to the prophet means the blassing from Allah to him and Shalawat from the mu'min or believers means the prayers for him and seeking forgiveness for him. Religious construction within the society of East Kalimantan has received influences from various groups and here includes the comers from other places who come and

\footnotetext{
${ }^{1}$ Koentjaraningrat, Pengantar Antropologi (Jakarta: Aksara Baru, 1974), pp. 76-77.

2 Mujiburrahman, “Aqidah dan Realitas Keberagamaan Masyarakat Banjar," Tashwirul Afkar, No. 26 (2008), p. 46.
} 
lived in East Kalimantan for decades. Habsyiyan tradition can be considered one example. The Habsyiyan tradition that is very popular in East Kalimantan actually has been developed by people at South Kalimantan initiated and promoted by the so called great teacher Zaini Ghani. This very respected teacher is commonly called as Ijai teacher is a descendant of the grand teacher Syaikh Arsyad Al-Banjari Kalampayan. So, there is a dialectical relation between Islamic teaching on one side and local culture on the other side within the religious life of Banjar society, not to mention influences from other varied elements. ${ }^{3}$

As mentioned above, the Habsyiyan tradition is mixture of religious values originated from Arab and local culture. From the short explanation above, this article will explore several issues as follows; (1) The ways in which the art tradition of Habsyiyan initially developed in East Kalimantan (2) The rituals and process of Habsyiyan (3) The influeces of Habsyiyan to the religiousity of the society.

\section{Early Development of Habsyian}

People of East Kalimantan is a pluralistic society with the composition of Javanese, Sulawesi, Banjar, Kutai, and others who come from different regions in Indonesia. Eventhough the background of religious affiliation is quite various, the religious activities resonance the model of abl al-sunnah wa al-jama'ah (Sunni). It can be said that there is no Muslim there affiliated with other school of theology like Shi'a or religious radical movements. The affiliation with sunni school of theology has brought religious activities in mosques or other places of worship (surau/musholla). Economically, the people from South Kalimantan (Banjar) are quite dominant in terms of economic ativities at East Kalimantan. Although their population is not the majority in the society, their role in shaping religious identity in East Kalimantan is significant. Most of Banjar immigrants are knowledgeable in Islamic teachings and most of them maintain the management of the mosque. They are well trained in Islamic boarding school (pesantren) in South Kalimantan.

One of an interesting feature of the Muslims in East Kalimantan is that most of the guardians or those responsible for the maintenance of the mosque (takmir masjid) are familier with and competent in performing the Habsyian tradition. They are exposed to it and learn to master the skill during their education and then in their later life they

\footnotetext{
${ }^{3}$ Ibid.
} 
socialize it in every mosque they manage. They bring tambourine (rebana) for performance and training purpose. They usually use this tradition as the media to attract people to come to the Mosque. And, after so many years, the Habsyian becomes routinely conducted activity and tradition embedded within the society of East Kalimantan. In thisregards, the role of Banjar people in disseminating Habsyian tradition is become a real evident.

The fact that Banjar people who live in East Kalimantan are mostly Muslim and do have a strong and good relationship with the surrounding society. Their religious life, style and many good deeds when interracting with people makes them well accepted by the society. They are using a compromistic and tolerant style in their interaction rather than confrontation. They hold very closely principle saying that dimana bumi dipijak disitu langit di junjung (wherever ground is stood on, the sky is held high) which means that one must adjust himself or herself to the local custom of the place he or she lived in. Another important feature to be noted from the Banjar people is that they have bravery and spirit to migrate to many places. They also hold strongly that three important modalities are faith, science, and spirit of work. It is by holding to these three principles, the Banjar society succesfully adjust themselves to the migration.

Most of the pesantren alumni in South Kalimantan come to the new local areas with spirit of proselytizing and preaching mission. Therefore, once they finished education, they have a common habit of travelling to various places bringing the preaching mission. They offer themselves to mosques in various places in order to be able disseminating and socializing their religious knowledge for at least one year in one place. The placement of these pesantren alumnies are not focused at the mosques but also at other places including companies and others insitutions. Once the period of their service in the respected place is finished, they will leave and move to other places while the new alumnies who are recently graduated come to that place and continue the tradition. Through this pattern, they introduce the religiocultural expression of Habsyian.

There are at least three important issues need to be addressed when we talk about social reality: first is research based data; second is selecting the focus of discussion; and third is the theoretical framework used to explain the facts. ${ }^{4}$ Habsyian is social reality that occurs in the

${ }^{4}$ Ibid., p. 47 
community of East Kalimantan as a product of acculturation between the local cultures with the Arab tradition. Interestingly, this acculturation processes have some dynamics within the society. Habsyiyan is one of the debated issues within the society. One of the commonly debated issue is the question whether it is permissible to perform Habsyiyan in holy places like mosque. Some will refuse the idea arguing that the habsyiyan is one example of heresy (bid'ab). In their opinion, there is order and or example given by the prophet regarding that tradition and therefore it can considered as bid'ah. And, they also believe that everything related to religion that has no clear prescription in the teaching should be banned. Different from this group, some other local scholars argue that they should see the benefits of the existence of Habsyian tradition in mosque as it surely brings favor and positive impact to the local community by attracting them to come more often to the mosque. ${ }^{5}$

In addition, as a means of preaching, the Habsyian tradition does bring peaceful messages by describing the figure of the Prophet Muhammad in the couplet and poems recitation. How the prophet is interacting with others and is well known for his kind heart is inspiring. Moreover, they also spread the message to the people that one of the main prophetic missions is to become blessing for the whole world (rabmatan li al-'alamin). Furthermore, the Habsyiyan tradition also promotes the importance of social solidarity. To give illustration, it is quoted from one of the Prophet's traditions stating that "God is always be with groups (jamäab)". Therefore, one of the idea of the Habsyian tradition is to make Muslim community solid as a group. Not only trough the message quoted from the prophet traditions but also trough the ways in which the rituals are conducted. The tradition basically is about people come and gather as a group and then recite the shawalat. So, it is actually the gathering and the unity through religious cultural performance.

\section{Habsyian and Its Rituals}

Habsyian tradition is a mixed form of art and spirituality. Eventhough the art aspect reflects the profane expression, the mission and values within it actually resonance the sacred dimension. The

\footnotetext{
5 See Abu Daudi, Transliterasi Kitab Tubfatur Raghibin (Martapura: YAPIDA, 2000), p.
} 20. 
esoteric dimension within a human is reached in the Habsyian tradition. It is believed as a means to revive spiritual resource to face the worldly matters. ${ }^{6}$ Recharging spiritual dimension seems to be the main objective of reciting poems on prophets Muhammad in Habsyian. They are imagining the presence of beloved person, Muhammad, among them and this really fuels them spiritually. They feel happy inside and feel very emotional to the extent that sometimes the tears slowly fall down. Thus, it is not only an artistic matter of cultural expression; it is more a spiritual manifestation. ${ }^{7}$

From observation and interviews, it is quite clear that many felt so touched when they recite sholawat to the prophet within the Habsyiyan rituals. They felt being in the presence of the prophet Muhammad. They recite the lyrics by imagining the figure of the prophet and hence they feel the excitment and the joy. They also felt being brought back to the times when the prophet received the revelation, the struggles in the wars. All the lyrircs also internalize the doctrines on the greatness of the characters of Muhammad as the prophet; one way is by reciting the verse from the Qur'an stating the compliment from Allah to the prophet as having the greatest characters. ${ }^{8}$

The textual book of badar prayings (maulid nabi) use in the Habsyiyan tradition is written by 'Alî b. Muhammad al-Habshi and it contains 33 poems. Here is some texts of badar praying,

Peace and blessing of Allah always be upon Thaha (Muhammad) the messanger of God, peace and blessing of God always be upon Yasin, the beloved of Allah.

We seek a way with Bismillah; and with the guide Rasulillah; and all who strive in the way of Allah; The People of Badr, ya Allah.

Oh my lord! Keep your people free; from hardship and adversity; From fear and sorrow and anxiety; Through your love of the people of the Badr, ya Allah.

\footnotetext{
${ }^{6}$ Danusiri, Epistemologi Dalam Tasawnuf Iqbal (Yogyakarta: Pustaka Pelajar, 1996), p. 34.

7 Banjar people usually tend to behave simple life, but they are strong in holding religious commitment. It is like habit that they are eager to read the story of Muhammad through habsyian tradition. Sometimes the event is being impressed when some one chanted each other to pray and send blessing to their prophet Muhammad. It seems that they imagine standing in fornt of Muhammad's tomb.

${ }^{8}$ Interview with ustadh Asrory, 4 December 2016.
} 
O God, please save and secure us from all damaged; and take us away from deceitfulness of the enemy; Please love us; Through your love of the people of the Badr, ya Allah.

And oh! What mercy we have acquired; How many misfortunes we're made to avoid; How great the blessings that have entered our lives; through your love of the people of Badr, ya Allah.

If you refuse, to whom should we ask all our necessities; o God who takes away all misadventure in the world and hereafter, please remove all from us through your love of the people of Badr, ya Allah.

Upon the sinless prophet blessings send; Beyond all count, beyond all end; on the blessed ones who from his descend; through your love of the people of Badr, ya Allah.

The poems mentioned above respectively comprises the virtue of love and hope of Muslim (reader) on how to revive the spirit of Muhammad and remember his effort and struggle in preaching Islam. This is the strategy believed to be effective in raising the motivation among the readers of the shalawat to learn from the prophet's life. The jam $\bar{a}^{\prime} a$ or the participant within the Habsyiyan are expected to be able to follow the prophet paths. ${ }^{?}$

In reading Simt al-Durar (salawat al-habsyi), there are some procedural ethics followed by the Habsyiyan followers and they are as follows:

1. Body, place and clothes should be clean (suci).

2. The participant should wear 'religious' clothes (cap, white clothes and sarong); new clothes are preferable; using parfume.

3. Facing the Qibla, if possible.

4. The forum leader begins with reciting opening poem, ya rabbi salli 'alā Muhammad.

5. And the reader of qasidah (munshid) should follow with rhyme, assalamu 'alaika zaynal anbiyai . It is allowed to recite it with some blowing tambourine, then it is followed by reciting a piece of Qur'anic verse, innā fatahnā laka fatḥan mubinā... wa mā muhammadun illa rasül... and then the opening is closed by the verse, laqad jäakum rasülun min anfusikum 'aqīizun 'alaybimā 'anittum harīisun 'alaikum bi al-mu'minina ra'üfun rabìm.

6. The forum leader begins to recite the first chapter of maulid, alhamdulillähi al-qawiyyi sultanuh till the end, and it is preceded by

\footnotetext{
${ }_{9}^{9}$ Kuntowijoyo, Paradigma Islam, Interpretasi untuk. Aksi (Bandung: Mizan, 1991), p. 38.
} 
reciting bismillāh... In the end of each sentence, the participant should follow and respond by reciting Sallu 'alayh.

7. The forum leader then continue to recite the second chapter, tajalla al-ḥaqqu $\overline{f i}$ 'älami qudsibi al-wasi'.. until the end, and when reading bibishäratin- laqad jäakum rasülun min anfusikum... and the participant should not follow the forum leader, but if they want to recite they should keep until the last sentence, raufun rahim.

8. The forum leader should continue to recite the third chapter, wa ashbadu an la ilāha illa alläha waḅdah..., and continue to the following chapter (the forth one) ammà ba'd.

9. The forum leader continues to recite the fifth chapter, wa qad ana li al-qalam... and afterwards the munshid could continue their qasidah recitation with musical instrument of tambourine.

10. Reciting the sixth chapter of simt al-durar, wa mundhu 'aliqat bibi bädhibi al-durrah al-maknunah ..., and should be continued to the next chapter, the seventh.

11. All participants are standing and this is called by the condition known as mahal al-qiyam, with reciting qasidah ashraqa al-kaunu ibtihajan... followed by tambourine if needed. Then, this could be the end of standing up and the participant could sit down in their place, and continued with religious preaching. It usually takes around 30-60 minutes.

12. When the preaching is finished, the people continues to recite the next chapter, eighth, wa hina baraza... This chapter gives story on the birth of prophet Muhammad. In this chapter, every single word should be read. They believe that this part is the essential one of reading simt al-durar. If the chapter is not read completely, it is deemed as if the previous readings is useless in relation to the reading of thesimt al-durar.

13. Continue to read the remaining chapters until the last chapter, the fourteenth, wa laqad ittasafa. This part can be read alternately by some readers.

14. In reciting the last part of simt al-durar, when the reader is reaching the page 56, that is the sentence, wa aqra'a al-salam, 'ala sayyidi al-anam... all participants could recite 'peace be upon Muhammad', and the following assalamu 'alayka ayyuha al-nabiy wa rahmatullähi wa barakätub for three times. This is considered the sacred moment. People say that they could follow it with fervent hearts and bowed heads, imagining as if they are standing in front of Muhammad's tomb in Medina and saying salam to him directly. 
15. The munsyid read qasidah followed by musical performance of tambourine. And then, the forum leader recites the last chapter, praying.

16. Before praying, they are usually preced it with salawat and reciting bismillāhi ar-rabmāni ar-rabìm, allābumma salli 'alā sayyidinā Muhammadin wa ala àlihi wa saḅbibi ajma'in and then follow it with reciting assalatu wassalamu 'alayka ya sayyidi al-mursalin... and finished by reciting al-fatibah.

17. In the last of praying, when they read the sentence wa äkbiru da'wāā 'ani al-bamdulilläbi rabbi al-'alamin... the forum leader should recite innallāha wa malaikeatahū yuslluna 'ala al-nabiy yā ayyuha al-ladhina àmanū sallū 'alayhi wa sallimū tastimā, sallühu 'alayka yā.. sayyidinā Muhammad, da'wâhum fīha subhanaka allābumma wa tabiyyatubum fīhā salän, wa ākhiru da'wähum 'ani alhamdulillähi rabbi al-'álamin.

18. The last one is reciting salawat upon Muhammad three times followed by reciting al-fatihah.

There are more complex and complete procedure of doing Habsyian rituals and it is usually performed in East Kalimantan. The duration is quite long. Those practices are recommended by the descendants of the author of simt al-durar. They belive that those ritual with that procedure will bring much blessings. Those who experience the ritual usually find theirself in serenity, joy and happiness. On the social dimension, the ritual of Habsyian makes them closer and more solid as a group. Additionally, it also significantly brings the growth of the economic solidarity for it has moved their emotion to feel compassion to others and become more actively contributive in social charity.

Based on their love to the prophet, they are eager to donate their wealth to buy 'gamis' clothes for others, set of tambourine and sound system, and etc. The social solidarity of the community has risen up from that moment. It seems that the collaborative event of religiocultural performance and the preaching of the local leader that make them more solid and harmony. The method of preaching used by local ulama or scholar has made evident to change social outlook. The ulama (habaib/ustädy) often preach Islamic teachings with their emotional quotient, so that they are frequently delivering speech with some tears on their face. The participants are definitely encouraged to revive their emotional to imagine how great the sacrifice of the prophet and his companions live among the cruel society of Mecca. 
The common tradition of Habsyian is usually led by a person sitting in front of the forum. He is the front man of the ritual. Beginning with reciting al-Fatibah, he then continue to recite some 'wirid' (praying) like tasbị̆ (praise and glorification of God) and istighfar (seeking forgiveness from God), reciting salawat upon the prophet Muhammad, and the participant directly respond by reciting salawat as well. Afterwards, the man maker or the forum leader begins to chant prayings and the prophet Muhammad stories in Arabic language written in the book of simt al-durar. The process of reading is quite long. Yet, people do enjoy to listen and follow the paths of ritual. Within the process, we will hear the participant shouted to each other in reciting the salawat upon the prophet Muhammad. The ritual is not boring because the musical instrument of tambourine added the melody to the rhythm of songs. The song and rhythm is not standardized. Each individual who recites the poems has his or her own cultural style. Usually, they made their own creativity and improvization to bring the ritual more melodious. People's creativity in reading simt al-durar has show great result in the advanced practices. Moreover, there is an annuall contest for the new improvisations of performing the Habsyiyan. Finacially, this competition is, in fact, supported by the local government .

Another unique feature commonly seen from the ritual of the Habsyiyan is that all participants are standing in the middle of ritual process. They are singing and chanting poems and reciting book of simt al-durar. There are also people walking around to give oil and parfume to the hand and clothes of participants. With the room full of fragrance, they imagine the presence of prophet Muhammad among them. The spiritual presence of prophet can be said as the important element making the ritual sacred. This tradition also takes place in tasmiyahan (the ritual of giving the name to the new child born). When all participants are standing, the newly born child is taken around by his/her father so that participants are seeing his/her face. Interestingly, there is also someone following them by bringing an open coconut shell. And, several scholars or prominent figures and the respected senior families or relatives are requested to cut a few of the baby's hair and put the hair inside of coconut shell. They are also splashing water to the face and the body of the baby. For them, this ritual is believed as a means to pray for the baby and wish him or her a bright and blessed life both in this world and the hereafter. 
Love and sense of art is a phenomenon of soul and is derived from purity in feeling. The delicataness of feeling of the so called 'arif billah or the people who know Allah and have the sense of love towards the God have been explored beautifully in the lyrics and poems within the riual. The ways in which the taste of art being poured in to the lyrics can sometimes go far from the pattern and norms. Yet, those are the ways in which the people can find pleasure and joy. This state of feeling and taste is the one commonly called as dzauqan shälih in Arabic term..$^{10}$

It is trough the Habsyiyan tradition, the feelings and emotions of many people are touched and moved to the extent that they also are actively donating and contributing to the run and management of the rituals. Some of them donate in forms of cash and others donate equipements such as clothes, terbang or gendang, sound system; all of the donaturs belive that these deeds reflect their love to the prophet. The social solidarity is constructed and strengthened particularly because of the messages spread by the habib and preachers during the rituals. The ways in which the habaib or preachers preach are very touching and persuasive. The habib and or prechers often cry when they give illustration on how the prophet and the companiates suffer from struggles in spreading Islam and encountering the hostility from the nonbelievers particularly the Quraish pagan. ${ }^{11}$

The rituals are usually closed by the prayers and preaching mostly about the the prophet. The preaching is quite effective as people listen to them carefully. This is due the conditioning resulted from the emotion brought by the rituals of reciting the shalawat. Here, when the soul is fully filled by the joy and peace, the messages from the preaching are easily absorbed. Theoretically, this is the ideal way of seeking knowledge and learning from the teachers in Islam. The students are supposed to give attention to the teachers in full concentration and show respect to the the preachers. It is believed that only within such condition, the messages and knowledges can be absorbed by the students and give impact to their live. ${ }^{12}$

10 Haderanie H.N, Ilmu Ketuhanan, Ma'rifat Musyahadah, Mukasyafah, Mahabbah (Surabaya: Nur Ilmu, n.d), p. 37.

11 Observation during the reading of the text of Habsyiyan on 3 October 2016 at Fathul Khair Mosque, Air Putih, District of Samarinda Ulu.

12 Obsevation on Habsyiyan activities in Islamic Centre, 12 November 2016. 


\section{Habsyian and the Influence to the Religiousity and Practices in the Society}

The tradion of Habsyian in some villages and cities influences some people to be interested in becoming its member and joining shalawatan. Moreover, many young people in Tanjung-PinangSamarinda join tausyiah from ustadz and babib that held during the Habsyiyan activities. In relation to Habsyiyan activities, it is clear that there is a potential of carrying messages of religious values. Religious education should be developed not only in the form of indoctrination on eternal-related matters such as heaven-hell, halal-haram, believer and non-believer but in the ways that the teaching can be relevant to the daily life. This way, the teaching of religion can be understood and accepted and practices in daily life. ${ }^{13}$ Religious values promotes and encourages positive behavior of a Muslim in every aspect; acts, deeds, words, the outfit. This is evident in the religious community of Habsyiyan in Samarinda. They are known for their good behavior, their uniquely good customs as well as in the ways they talk and interact with others. It can be said that they have internalized the values and spirit from the sholawat they routinely recite.

Habsyiyan community has a high solidarity and loyalty among them. They have uniformity in their clothes and attributes. They also have their own characteristics. Another important point is that there are many Habsyiyan groups exist in Kalimantan. And, they gather routinely by arranging festival of Habsy in various cities across East Kalimantan.

From the observation on the habsyiyan groups and activities, it is quite clear that they are a religious group which far from radicalist views let alone violence or any terrorism act. Their presence and performance at every event they attend is actually under invitation by the commnity. To understand this, it is important to note that sholawat is quite popular within the society at kalimantan. The trend of Habsyiyan tradition and groups is not exclusive to men but also existed among women. They are popular in the neighborhood groups as well as in the government.

The high popularity of Habsiyan tradition has given its own color in religious life in East Kalimantan. This is due to their believe in may texts that urge and encourage the reciting of sholawat. The texts or the

${ }^{13}$ Isrofil Amar, "Studi Normatif pendiidikan Islam Multikultural," ISLAMICA, Vol 4, No. 2 (March 2010), p. 321. 
religios basis as arguments have been held strongly by people. And, it is interesting to see that this normative basis is also reintroduced and being maintained to spread and being reminded to people trough the texts of the Habsyiyan shalawat recited routinely. One of the phenomenon is that the government of East kalimantan invite the Habib (descendants of the prophet) from Arab ethicity to perform and lead the shalawat fesitivals. It seems that government understand and respond to the trend within the society.

East Kalimantan is one of a very vast territory and is three times bigger than Java. The society is also diverse. In this sense, the proliferation and the spread of these Habsyian Arab tradition throughout the cities and districts plays role as unifying the people who actually are very diverse in culture, socio-economic and ethnicities. refJavanese is the majority of pupulation in East Kalimantan followed by Sulawesi and then Banjarese, Kutai and other various other tribes in Indonesia.

It can be said that East Kalimantan is a miniature of Indonesia as it has various ethcnicities along with their diverse cultures and characters. Even though it is also geographically wide and big, the condition of the society is harmonious. It is probably also due to the fact that they are quite homogeneous in terms of religion adherence. In addition, there are many nationality-based forums such as FKUB, (Communication Forum for Inter-faith Communities) FKPT (Communication Forum for Terrorism Prevention) that function as advocates for the unity and interfaith harmony.

The Habsyiyan tradition also shapes the economic life as there are many people who sell clothes and tool-tool related to the tradition. Another impact is that the piety as a lifestyle is internalized and introduced since the early stage of life as this tradition is popular among all people covering children and adults. The fans of this habsyyan can be found in all layers of the society. The tradition is that after the reading of shalawat there is religious speech or sermon delivered by Habaib. The content of the speech mainly is about Principles of equality before the law, protection of citizens from injustice and arbitrariness, custody rights of the weak, as well as limitations on the authority of those in power. All these ideas exposed 
by the preachers, who are mostly habaib, actually are evidence on the openness of Islamic civilization. ${ }^{14}$

Preaching missions of the habaib are to to spread and broadcast islam as peace and bless exactly just like Islam brough by the Prophet. They want to deliver this kind of teachings to all mankind. The Prophet figure is mentioned in the Qur'an as rahmatan li al-'alamin, and as "role model". Here, Islam with its universality in values is the religion supposed to be held strongly by the people. The universalism of Islam is evident as it is belived by the adherents as the only religion that is final. It is this unversality of Islam that is the main idea of the preaching mission of the babaib trough their Habsyiyan shalawat tradition. They seem to avoid emphasizing differences. Rather, they will promote and put highlight more on the sameness so that the unity will be promoted. They often quote the verse stating the the most noble person to Allah is the most God fearing. This is to support their promotion on equality principle. They go and visit and preach acrross villages in various cities in East kalimantan be it a great festival or small occasions at the community. The success of the religious social movements requires a very long process started from the incubation period, the action and the institutionalization. In addition, there are some conditions needed to support the realization of a movement.It is clear that Islam is the religion that can be role model. There are several characters of Islam: (1) Rabbaniyah, (2) ash-shumul (in common); al-wäii iyyah (rests on the objective reality of man). From the nature of al-waqi'iyyah, the issue of Islamic universalism can be understood more clearly. ${ }^{15}$

The couplets of shalawat to the Prophet glorify the nature Rabbaniyyah Illabiyah, as-shumuitiyah and al-waqiiryyah resting on the objective fact. The Habsyian Arab tradition here is functioning as a means of attracting people to attend the gathering. Due to its popularity among people in East Kalimantan, the Habsyiyan rituals and gatherings really have power to attract people and therefore functions perfectly as adhesive. Furthermore, as the main content of the rituals are the shalawat and the praises to the prophet, the story of the prophet, the good deeds of the prophet, and other good praises, it is not surprising that the effect to the people is also positive. They love to hear beautiful stories of the prophet and when internalized, a sense

\footnotetext{
14 Budhi Munawar Rachman (ed.), Kontekstualitas Doktrin Islam Dalam Sejarah (Jakarta: Paramadina, 1995), p. 545.

${ }^{15}$ Hasbullah Bakri, Di Sekitar Filsafat Skolastik Islam (Jakarta: Tintamas, 1973), p. 2.
} 
of tranquility with the feeling of nostalgic flasing back to the history of the struggle of the Prophet emerge. For example, one of the frequently told story within the couplet of the Habsyiyan tradition is the story of the prophet's struglle in fighting the non-believers from Quraish in the "Badar" war. The story on the gap between the number of Muslims and their enemies at the war; 300 Muslims and 1000 non-believers is exposed to give illustration on how scary the situation was. Afterward, it is also told to the people the way the prophet asks for God's help and looked up his hands to the sky and said, "O Allah if only we defeated by these enemies who deny you in this war, there will be no one saying Là Ilāha Illà Allāh" anymore on earth. The main point of the story is when Allah then sent down helping troops from the sky that can not be seen by the enemies and resulted in the big victory of the Muslims. Most of the time, the Stories of struggle of the Prophet told by the habaib and religious leaders do raise emotion among the audiences and make them moved.

Another important feature of the the rituals held by the Habsyian in religious groups or any other occasion is that they never offend one's own mistakes. They also neither raise the issue of differences between groups nor they inflate sesntive issues regarding diversity in religious opinios or even difference between religions. They will put emphasize and focus on calling people to obey the command of Allah and avoid His prohibitions, praying for their fellow Muslims so that all can receive guidance from the God.

The routine participation of the Habsyiyan followers that allow them frequently exposed to the history of the prophet actually does lead to them being inspired to take the propet as the role model in their daily life. They are encouraged to always deepen and broaden the knowledge and horizon, be good and kind to people and always hold the religious norms in their life as a muslim. Here, it is also assumed that the intensive exposure to shalawat routines have brought the calmness and energy to life the fullest of their life and to be able to encounter problems. This is actually what is called as sugesty in psycology.

\section{Habsyi and Local Culture}

Practices within the local culture remain maintained to be part of the Islamic teachings. The existence of tradition and socio-cultural insitutions are maintained as long as they do note contravene the universal Islamic 
teaching in Qur'an. The tradition like Habsyiyan tradition with the recitation of shlawat to the prophet, celebrating the birth of the prophet and other traditions or socio-cultural insitituions like tablilan, manaqiban, mauludan, rajaban, syawalan that have been the part of the society at East Kalimantan actually is the result of the inculturation of the local culture with Islam. In symbolic manner, they actually are originated from preIslam, but, the substance are originated from Islam. ${ }^{16}$

The traditions are being incorporated to Islam, some might call it as being Islamized, trough the processes of adoption, adaptation and integration. The form of the practices might be still similar with those in the pre-Islam. However, the ways in which the practices are perfomed as well as the substance, including the message of the tradition, has been gon trough adaptation so that they are in line, or at least do not contravene the teaching of Islam. The variety of local Islamic traditions within the society can not be understood as the deviation from the orthodox allowing the birth of the tradition of the majority (great tradition). The existence should be seen and understood as the interpretation of the teachings and believes in the orthodox brought into reality within the society. The consequence here is the emergence of heterodoxy. In relation to this, every matter and debates regarding the issue of local tradition and Islam, in my opinon, should be brought back to maqasid ash-shari $a$ ah and the principle of Qur'an teaching that is to attain the benefit in life. Islam does not demand uniformity. This is due to the fact that God has created the creatures in diversity. It is the nature of God's law. The diversity and plurality is not there to be resisted let alone to be eliminated. Rather, it has to be accepted as the fact that also will complement the function of the leadership of Man on earth.

With this thought as a fundamental principle, people have equal right and obligation and among them is to respect the ters, being tolerant and respectfull towards diversity and plurality. Here the importance of respect for cultural differences in each group within society. As a matter of fact, there respect and appreciation to the art and expressions of culture and tradition as they are actually resulted from human instinct to develop and employ the power of creativity, initiative and the work that led to the creation of ideas, activity, and the excitement of working in the arts. The tradition of Habsyian is one

16 Ali Sodikin, Antropologi Al-Qur'an, Model Dialektika Wabyu Dan Budaya (Jakarta: ArRuzz Media, 2010), p. 210. 
good example. This tradition that also takes form in cultural art and expression developed in East Kalimantan and actually has undergone stages and one of them is by gathering various and diverse cultural and ethnic characters to become one entity. They have common aim and mission that is to spread the message of monotheism and God-fearing. They also focus on calling people to be awaken and take their leadership role more seriously, particularly in their missions to preach and spread the values of Islamic teaching to all mankind.. ${ }^{17}$

Here, it can be said that Local cultural practices are not only incorporated but more than that, they also become the basis of the spread of Islamic teachings. Muslims in Kalimantan do maintain the existence of traditions or socio-cultural institutions that already exist pre-Islam and they will be retained as long as they do not contravene the principle of Qur'an. Here, Qur'an has position as the guiding line for the process of customs enculturation. This way, Muslims do not necesssarily have to loose their tradition. It lies the authenticity of Islam, that is, when people practice their religion in its cultural context. Habsyian Islamic cultural-art that flourished in East Kalimantan have a positive impact in the spread of Islam in a peaceful way as they are using the so called nada dan dakwah or 'preaching and music'. So, it is a counter productive act to ignore, moreover, to refuse and diminish the tradition. In addition, it also actually is not new in relation to religious discourse.

It is better, in this case, to hold to the rules "maintaining and preserving the good old tradition from the past with taking the new and better things". Good tradition has to continue to be developed while we also have to improve and develop newer and better method and manner of preaching especially with the complexity of cultures and challenges nowadays. These so called traditions like Habsyiyan shalawat rituals actually functions no more that the means to promote religious piety in the way that is familiar with the laymen. ${ }^{18}$

Habsyiyan tradition actually use the history to promote the message of how muslims should and could duplicate the role model of the prophet in his deeds, his consistency, his patience as well as his bravery in the struggles to spread Islam. The couplets of the Habsyiyan rituals of shalawat also contain knowledge and here they function in

${ }_{17}$ Endang Saifuddin Ansharri, Ilmu Filsafat dan Agama (Surabaya: Bina Ilmu, 1987), p. 127.

${ }^{18}$ C.A. Qadir, Filsafat dan Ilmu Pengetabuan Dalam Islam (Jakarta: Yayasan Obor, 1991), p. 6. 
promoting education to the people through the art. History shows that the progress of a nation in this world is closely related to the quality of the knowledge of the people. This is due to the fact that it is knowledge and science that brings a nation to glory and power. 19 Here, it can be said that the Habsyiyan is developed as means for preaching just like the mission of preaching of $W$ ali Songo or the nine saints in Java being effective using the local culture that is $W$ ayang. ${ }^{20}$

\section{Conclusion}

There are several points can be concluded from the discussion above. One is that Habsyiyan is an Islamic cultural art that has been a part of Muslims in East Kalimantan. This tradition is based on the love and affection of the people to the prophet Muhammad. In the rituals, they will recite shalawat and read them to the prophet. The couplets also contain praises to the God like tasbih, and takbir and some verses of the Qur'an.

Historically, it has developed since a long time ago brought by Banjarese who mostly work as merchants and preachers. Most of them are graduates from pesantren or Islamic boarding schools in South Kalimantan. They idolize the songs of shalawats taught by their teacher and leader Zaini who clearly becomes the inspiration for them and for the Habsyiyan movements in East Kalimantan.

The tradition has the normative basis as reciting shalawat to the Prophet is urged by Islam with many texts urging it in Quran and hadiths. One basis is found in verse 56 of Sura Al-Ahzab. There are also many hadith show the order to muslims to recite shalawat to the prophet.

The procession of the ritual itself is unique and interesting. There are some conditions expected to be followed by the people joining the ritual. They are expected to wear nice certain clothes; white and clean, using fragrances, coming with happy face and facing towards the qiblab whenever possible. There will be a leader who leads the ritual and he will start with shalawat followed by reciting the fourteen couplets. One tradition is also that the leader will recite shalawat 'Assalatu wassalamu 'alaika ya sayyidil mursalin as if they are coming directly to the front of the grave of the prophet.

\footnotetext{
${ }^{19}$ Ibid.

${ }^{20}$ H. Abdullah Siddik, Islam Dan Ilmu Pengetahuan (Kuala Lumpur: Dewan Bahasa dan Pustaka, Kementerian Pelajar Malaysia, 1994), p. 136.
} 
One of the most important thing observed from this phenomenon is that the tradition actually is a means of preaching. More importantly, the main message and mission they tried to bring and spread is the promotion of peaceful Islam. They tend to avoid giving emphasize to the differences or anything that potentially leads to confrontations. Rather, they will highlight the examples from the role model that is the prophet and encourage people to idolize him and follow him in deeds and attitudes. The existance of Habsyian in East Kalimantan inflicts pro and contra among society. That is due to some various schools of thought that have different views.

As a means of preaching and propagation, the Habsyiyan do have significant influences in shaping the life of people in East Kalimantan. From the theoretical aspect, preaching has to consider the method and approach used to be effective. Here, using the local wisdom as an approach is one good strategy especially when it is perceived as a means to raise the potentials of the ummah (people) and empower them. With the wisdom of Local Islam that respects and appreciates local culture, cultural plurality, diverse ethnics, the preaching and spreading of Islam will attract people as they will not feel intimidated for being who they really are. This is the actual strength of Islam that is able to adapt, adopt and integrate. Islam does not force uniformity. Instead, it respect diversity.

Meanwhile, viewed from the practical aspect, it is evident that Habsyiyan tradition does give positive impact to many people. People learned to revive their faith and also learn how to fulfill their duties in accordance to the teaching of Islam. One of the impact is that people are not in a static position but in a dynamic movement that encourage them to always improve themselves. Here, Qur'an becomes the central of the preacing of the Habsyiyan and plays a strategic role as the unifying factor to bridge the diversity among the muslims themselves.]

\section{References}

\section{Books and Articles}

Ali, H.A Mukti. Ilmu Perbandingan Agama Suatu Pembabasan Tentang Metode Dan Sistem. Jakarta: Tinta Mas, 1993.

Asy'arie, Musa. Islam Dan Iptek Dalam Kehidupan Manusia, Suatu Pendekatan Filosofis. Jakarta: Paper for seminar in University of Indonesia, 1995. 
Anshari, Endang Saifuddin. Ilmu Filsafat dan Agama. Surabaya: Bina Ilmu, 1987.

Amaan, Isrofil. "Studi Normatif Pendidikan Islam Multikultural." ISLAMICA, Vol 4 (2010)

Abdullah. M. Amin. "Demensi Etis Teologis Dan Etis Antropologi Dalam Pembangunan Berwawasan Lingkungan." Al-Jamiah, No. 49 (1992)

Bakri, Hasbullah. Di sekitar Skolastik Islam. Jakarta: Tintamas, 1973.

Daudi, Abu. Transliterasi Kitab Tubfatur Raghibin. Martapura: n.p., 2000.

Danursiri. Epistemologi Dalam Tasawuf Igbal. Yogyakarta: Pustaka Pelajar, 1996.

Fazlurrahman. Islam. Bandung: Mizan, 1984.

Koentjaraningrat. Pengantar Antropologi. Jakarta: Aksara Baru, 1974.

Mujiburrahman. "Aqidah dan Realitas Masyarakat Banjar." Tashwirul Afkar, No. 26 (2008).

Syukur, Suparman. Epistemologi Islam Skolastik Pada Pemikiran Islam Modern. Yogyakarta: Pustaka Pelajar, 2007.

Suwandi. "Oreintasi Kurikulum Integratif-Interkonektif Menuju Pencaoaian Sasaran." Jurnal Penelitian Agama, Vol XVII, No. 1 (Januari-April, 2008).

Qadir, C. A. Filsafat Dan Ilmu Pengetahuan Islam. Jakarta: Yayasan Obor, 1991.

Siddik, Abdullah. Islam Dan Ilmu Pengetahuan. Kuala Lumpur: Dewan Bahasa Dan Pustaka, Kementerian Pelajar Malaysia, 1994.

Ali, Sodikin. Antropologi Al-Qur'an, Model Dialektika Wabyu Dan Budaya. Jakarta: Ar-Ruzz Media, n.d.

Wahid, Abdurrahman. Kontektualitas Doktrin Dalam Islam. Jakarta Paramadina, 1995.

Syarif, M.M. Dialektika Islam; Alam Pikiran Islam. Bandung: CV Diponogoro, 1970. 